\title{
Minat Mahasiswa Perbankan Syariah Melakukan Pembayaran Transaksi Non Tunai Berbasis Web
}

\author{
Fitri Nur Latifah, M. Ruslianor Maika, Nuril Lutvi Azizah \\ Universitas Muhammadiyah Sidoarjo
}

fitri.latifah@umsida.ac.id,mr.maika@umsida.ac.id,nurillutviazizah@umsida.ac.id

\section{Article Info}

Article history:

Received Oct19th, 2020

Revised Oct 30th, 2020

Accepted Nov 5th, 2020

\section{Keyword:}

Non-Cash transactions,

Virtual Account,

Ijabqabul.id

\begin{abstract}
Bank Indonesia made a policy of a national movement of cashless transaction, expected to have positive impacts on a country's economy. Aims this study trying to explore the potential of non-cash transactions by using a web application in the ijabqabul.id platform as well as knowing the system description, business models and students' interests, especially Islamic banking students at Muhammadiyah University of Sidoarjo in non-cash transactions using web-based applications, where they have made non-cash transactions several times when paying for participation in seminars or training activities organized by the campus and payment through a virtual account issued by IjabQabul.id. Where we will examine how much interest students have in conducting non-cash transactions and what are the positive effects and conveniences that will be obtained by these students.
\end{abstract}

Copyright@2020 Program Studi Ekonomi Syariah Universitas Yudharta Pasuruan All rights reserved.

DOI: https://doi.org/10.35891/ml.v12i1.2005

\section{Corresponding Author:}

Fitri Nur Latifah,

Lecturer at the University of Muhammadiyah Sidoarjo

Email: fitri.latifah@umsida.ac.id 


\section{A. Pendahuluan}

Penelitian ini didasari oleh dua isu utama. Isu pertama adalah mengenai pola hidup masyarakat yang akan berubah menjadi perilaku konsumtif seiring dengan perkembangan teknologi pada sektor jasa pembayaran (Didin Elok Parastiti, Imam Mukhlis, 2015), Kedua, Indonesia memiliki potensi yang besar menuju cashless society, berdasarkan data yang dari Worl Bank Populasi penduduk Indonesia sebanyak 261.120.000 jika, yang sudah terakses bank baru 46,9\%, dimana tingkat penggunaan internet sejumlah 143,2 juta pengguna (30\% menggunakan desktop dan $70 \%$ menggunakan mobile), dengan tingkat pertumbuhan ekonomi Indonesia sebesar 5\%. Masyarakat Indonesia yang menggunakan skema pinjaman dari institusi keuangan sebesar 17,2\%. Jika dilihat dari penggunaan fintech di Indonesia kebutuhan untuk pembayaran masih menempati posisi tertinggi yakni sebesar 38\%, kemudian untuk pinjaman online sebesar 31\%, sedangkan untuk kebutuhan lain seperti asuransi, crowdfunding, cryptocurrency dan blockchain dan lain sebagaianya penggunaannya masih rendah rata-rata masih dibawah 10\% (Rahmat Mulyana, 2019),

Jumlah perusahaan financial technology (Fintech) Indonesia pada 2017 mencapai 153. Dari jumlah tersebut, $40 \%$ bergerak di bidang jasa pembayaran. Sedangkan $23 \%$ di bidang usaha pinjaman, $12 \%$ di bidang usaha aggregator. Sementara startup financial di bidang usaha perencanaan mencapai $7 \%$ dan crowdfunding 7\% (databoks, 2017), sampai dengan data per 30 September 2019 menunjukan total perusahaan fintech yang resmi berizin dan terdaftar di OJK sebanyak 127 perusahaan (Keuangan, 2019) sehingga dengan presentase $40 \%$ perusahaan yang bergerak di bidang payment menjadi domonasi dalam perusahaan financial technology. Mendominasinya sistem pembayaran (payment) pada perusahaan fintech terjadi karena adanya inovasi dalam produk pembayaran. Inovasi adalah salah satu landasan bagi masa depan masyarakat, dengan adanya inovasi pada produk pembayaran berbasis elektronik memberikan dampak potensial pada pengguna uang tunai karena semakin banyak alternatif yang tersedia bagi masyarakat umum yang awalnya biasa melakukan pembayaran secara tunai kini bergeser kebiasaan melakukan pembayaran dengan non tunai (cashless) yang menyebabkan perubahan perilaku dan gaya hidup masyarakat menjadi lebih konsumtif.

Hal tersebut sejalan dengan pertumbuhan pengguna internet yang menjadi faktor penting dalam mendukung pertumbuhan dan perkembangan ekonomi digital di negeri ini. Pengguna internet di Indonesia pada 2018 sebanyak 95,2 juta, tumbuh 13,3\% dari 2017 yang sebanyak 84 juta pengguna. Pada tahun selanjutnya pengguna internet di Indonesia akan semakin meningkat dengan rata-rata pertumbuhan sebesar $10,2 \%$ pada periode 2018-2023. Pada 2019 jumlah pengguna internet di Indonesia diproyeksikan tumbuh 12,6\% dibandingkan 2018, yaitu menjadi 107,2 juta pengguna (Kusnandar, 2019).

Dalam sistem pembayaran non tunai ini, Universitas Muhammadiyah Sidoarjo bersama unit usaha e-commerce IjabQabul.id menerapkan sistem pembayaran menggunakan virtual account dengan tujuan memudahkan mahasiswa ketika proses transaksi dilakukan. Virtual account ini berupa nomor identifikasi yang dibuka oleh Bank atas permintaan Unit Usaha Ijabqabul.id untuk selanjutnya diberikan oleh Unit Usaha 
Ijabqabul.id kepada mahasiswa sebagai No Rekening Tujuan penerimaan (collection) (Siahaan, 2016). Seminar Internasional "The International Seminar On Science and Religion in the Indonesia and Malaysian Education System" merupakan kegiatan pertama yang menggunakan sistem pembayaran non tunai. Kegiatan ini dilaksanakan pada bulan Juni 2019, namun mahasiswa yang melakukan transaksi pembayaran menggunakan virtual account baru sebesar 7\% dari tolal keseluruhan. Artinya dengan jumlah peserta sebanyak 400 mahasiswa hanya 26 mahasiswa yang baru menggunakan transaksi non tunai. Kegiatan seminar selanjutnya yang menggunakan pembayaran non tunai adalah Seminar Nasional "Peran Ekonomi Islam dan Keuangan Syariah di Era Revolusi Industri 4.0" yang dilaksanakan pada Juli 2019 dengan 500 peserta dan presentase pembayaran non tunainya hanya sebesar $11 \%$. Namun kenaikan terjadi jumlah pengguna pembayaran non tunai, terbukti pada September 2019 tercatat sebagai kegiatan seminar ketiga yang dilakukan oleh Universitas Muammadiyah Sidoarjo dengan metode pembayaran melalui virtual account dengan jumlah peserta sebanyak 800 mahasiswa presentase transaksi dengan menggunakan VA sebesar 69\%, artinya lebih dari setengah jumlah peserta yang melakukan transaksi non tunai.

Berdasarkan latar belakang yang telah dipaparkan diatas penulis menyimpulkan bahwa merubah kebiasaan mahasiswa yang biasa melakukan transaksi tunai menjadi transaksi non tunai membutuhkan inovasi dan waktu yang tidak singkat mengingat tingkat kesadaran (awareness) mahasiswa akan transaksi non tunai yang masih rendah, sehingga menimbulkan berbagai pertanyaan dan pemikiran bagi penulis untuk mencari solusi yang inovatif dengan harapan solusi tersebut dapat membantu dalam menyelesaikan masalah yang dihadapi oleh mahasiswa Universitas Muhammadiyah Sidoarjo.

\section{B. Kajian Teori}

\section{Financial Technology}

Gelombang revolusi dalam bidang teknologi digital secara cepat dan massif bergerak masuk hampir ke semua aspek kehidupan dan ekonomi masyarakat dunia, seperti transportasi, kesehatan, pendidikan, ritel, hotel, dan bahkan keuangan. Di sektor keuangan sendiri kini berkembang dengan istilah financial technology (Fintech) yang didefinisikan sebagai inovasi teknologi dalam layanan keuangan yang dapat menghasilkan model-model bisnis, aplikasi, proses atau produk-produk yang terhubung dengan penyediaan layanan keuangan (Muzdalifa, Rahma, \& Novalia, 2018).

Transaksi keuangan melalui fintech dapat meliputi berbagai kegiatan ekonomi diantaranya: pembayaran, investasi, peminjaman uang, transfer, rencana keuangan dan pembanding produk keuangan. Fintech saat ini diakui sebagai satu inovasi paling penting dalam keuangan industri dan berkembang dengan cepat, selain itu industry fintech dapat tumbuh dengan cepat karena didukung oleh peraturan yang menguntungkan dan teknologi informasi . Fintech mempunyai visi untuk membentuk kembali industri keuangan dengan memotong biaya, meningkatkan kualitas layanan 
keuangan, dan menciptakan lahan keuangan yang lebih beragam dan stabil. Disisi lain kemuculannya fintech juga akan berdampak membentuk sebuah lanskap keuangan dan perbankan yang baru dengan berbasis teknologi (Wardhana, Mukminin, Syafira, Isnawati, \& Latifah, 2020).

\section{Cashless Payment}

Perkembangan sistem pembayaran diiringi dengan perkembangan teknologi (Tazkiyyaturrohmah, 2018). Dahulu sistem pembayaran dikenal dengan kata barter, barter adalah cara alternatif untuk mendapatkan barang dan jasa tanpa membayar dengan uang tunai dengan ketentuan dari kesepakatan barter harus dinegosiasikan sampai kesepakatan dicapai oleh semua pihak yang terlibat (Taskinsoy, 2019). Sedangkan dalam islam barter diperbolehkan dengan syarat harus sama dan secara tuanai. Sistem pembayaran kemudian berkembang dengan munculnya suatu alat untuk bertransaksi yang memiliki nilai dengan satuan tertentu disebut uang. Hingga kini pesatnya perkembangan financial technology (fintech) menciptakan inovasi baru dalam sektor jasa keuangan khususnya pada sistem pembayaran, guna memaksimalkan penggunaan pembayaran non tunai (less cash) sehingga terciptanya masyarakat tanpa uang tunai (less cash society).

Maraknya pembayaran transaksi non tunai pada masa kini membuat masyarakat mulai beralih dalam hal perilaku bertransaksi dari transaksi manual dengan menggunkan uang tunai sebagai alat transaksi ke transaksi tanpa uang tunai (less cashless) (Amalia, 2018). Hal ini terkait dengan perkembangan sistem teknologi informasi dan komunikasi yang dapat meningkatkan efisiensi sistem pembayaran serta mengurangi waktu dan biaya yang diperlukan untuk melakukan transaksi (Usman, 2017). Adanya sistem cashless society juga sejalan dnegan dicanangkannya program Gerakan Nasional Non Tunai (GNTT) oleh Bank Indonesia pada tahun 2014 dengan tujuan untuk meminimalkan pengunaan transaksi uang tunai di masyarakat (Indonesia, 2014).

\section{Dampak Cashless Policy di Indonesia}

Dorongan untuk melakukan transaksi non-tunai dengan adanya cashless policy di Indonesia diharapkan dapat memberikan dampak yang positif bagi perekonomian. Dari penelitian terdahulu dapat disimpulkan bahwa transaksi non-tunai membawa dampak positif bagi perekonomianseperti pertumbuhan ekonomi danpertumbuhan pada UMKM. Selain itu, efisiensi kenyamanan transaksi juga menjadi dampak positif yang didapatkan konsumen.

Meskipun begitu, ada beberapa tantangan yang harus dihadapi delam rangka penerapan transaksi non-tunai yang efisien diantaranya ada;ah tingkat penerimaan konsumen, infrastruktur yang memadai, keamanan transaksi non-tunai, proses migrasi dari transaksi tunai ke bnon tunai dan juga potensi menumbuhkan perilaku konsumtif pada konsumen. Dalam menghadapi tantangan tersebut, perlu adanya kemampuan dan mitigasi resiko yang layak. 
Di Indonesia regulasi tentang hal ini sudah cukup baik dari OJK maupun MUI. Pengembangan infrastruktur tentang pembayaran non-tunai diharapkan bisa dapat terus meningkat sehingga bisa berkontribusi pada perekomian Indonesia yang lebih baik lagi di masa depan.

\section{Metode}

Berdasarkan rumusan masalah maka tujuan yang ingin dicapai dalam penelitian ini adalah untuk menganalisis dan mengkaji minat mahasiswa Perbankan Syariah Universitas Muhammadiyah Sidoarjo dalam melakukan pembayaran transaksi non tunai berdasarkan web.

Metode yang kami gunakan dalam penelitian ini adalah metodologi kualitatif menggunakan pendekatan fenomenologi (Stan Lester), untuk mendapatkan data melalui pengumpulan informasi dan persepsi 'mendalam' melalui metode induktif, kualitatif seperti wawancara dan diskusi. Hal ini didasarkan pada paradigma pengetahuan dan subjektivitas pribadi, dan menekankan pentingnya perspektif dan interpretasi pribadi. Karena dengan ini peneliti dapat memahami pengalaman subjektif, mendapatkan wawasan tentang, dimana kami akan melakukan survei kepada responden dalam hal ini adalah mahasiswa perbankan syariah semua angkatan. Kami akan melihat sejauh mana minat responden dalam melakukan pembayaran non tunai dengan media web, apa saja respon mereka dan akan kami analisa setiap respon dari responden tersebut sesuai dengan teori yang ada dan kondisi riil di lapangan.

Teknik pengumpulan data yang kami gunakan dalam penelitian ini untuk mendapatkan informasi dan data dilakukan melalui kuesioner, wawancara, studi kepustakaan (literature), dokumentasi dan observasi. Dalam menganalisis data dilakukan dengan pengumpulan data, reduksi data, penyajian data dan penarikan kesimpulan

\section{Hasil dan Pembahasan}

Pada penelitian ini penulis menggunakan pendekatan fenomenologi (Stan Lester), untuk mendapatkan data melalui pengumpulan informasi dan persepsi 'mendalam' melalui metode induktif, kualitatif seperti wawancara dan diskusi. Hal ini didasarkan pada paradigma pengetahuan dan subjektivitas pribadi, dan menekankan pentingnya perspektif dan interpretasi pribadi. Karena dengan ini peneliti dapat memahami pengalaman subjektif, mendapatkan wawasan tentang minat mahasiswa perbankan syariah melakuan transaksi non tunai berbasis web, penelitian ini melibatkan unit usaha program studi perbankan syariah yakni Ijabqabul.id yang merupakan platform fintech syariah. Dalam kegiatan pembayaran non tunai ini biasa digunakan untuk pembelian buku, pembayaran kepesertaan pada acara seminar atau confrence.

Sebagaimana kita ketahui banyak perguruan tinggi sudah menerapkan pembayaran cashless dalam mendukung program less cashless society, Universitas Muhammadiyah Sidoarjo pun mulai menerapkan pembayaran dengan sistem cashless. Namun lain halnya dengan kampus sebelumnya, Universitas Muhammadiyah Sidoarjo menerapkannya pada kegiatan internal seperti seminar yang sering diadakan namun 
masih menggunakan sistem pembayaran secara tunai yang dinilai kurang efektif karena harus ada pertemuan antara mahasiswa yang hendak membayar dengan pengurus kegiatan. Oleh karena itu Universitas Muhammadiyah Sidoarjo bekerja sama dengan PT. Ijabqabul Muamalah Indonesia yang merupakan perusahaan financial technology untuk sama-sama mewujudkan transformasi dari pembayaran non tunai (less cashless) yang kurang efisien menuju less cash society yang identik dengan penggunaan uang elektronik yang aman dan efisien di lingkungan Universitas Muhammadiyah Sidoarjo.

Dalam sistem pembayaran non tunai ini, Universitas Muhammadiyah Sidoarjo Bersama Unit Usaha Ijabqabul menerapkan sistem pembayaran menggunakan virtual account dengan tujuan memudahkan mahasiswa ketika proses transaksi dilakukan. Virtual account ini berupa nomor identifikasi yang dibuka oleh Bank atas permintaan Unit Usaha Ijabqabul untuk selanjutnya diberikan oleh Unit Usaha Ijabqabul kepada mahasiswa sebagai No Rekening Tujuan penerimaan (collection) (Siahaan, 2016). Seminar Internasional "The International Seminar On Science and Religion in the Indonesia and Malaysian Education System" merupakan kegiatan pertama yang menggunakan sistem pembayaran non tunai. Kegiatan ini dilaksanakan pada bulan Juni 2019, namun mahasiswa yang melakukan transaksi pembayaran menggunakan virtual account baru sebesar 7\% dari tolal keseluruhan. Artinya dengan jumlah peserta sebanyak 400 mahasiswa hanya 26 mahasiswa yang baru menggunakan transaksi non tunai. Kegiatan seminar selanjutnya yang menggunakan pembayaran non tunai adalah Seminar Nasional "Peran Ekonomi Islam dan Keuangan Syariah di Era Revolusi Industri 4.0" yang dilaksanakan pada Juli 2019 dengan 500 peserta dan presentase pembayaran non tunainya hanya sebesar $11 \%$. Namun kenaikan terjadi jumlah pengguna pembayaran non tunai, terbukti pada September 2019 tercatat sebagai kegiatan seminar ketiga yang dilakukan oleh Universitas Muammadiyah Sidoarjo dengan metode pembayaran melalui virtual account dengan jumlah peserta sebanyak 800 mahasiswa presentase transaksi dengan menggunakan VA sebesar 69\%, artinya lebih dari setengah jumlah peserta yang melakukan transaksi non tunai.

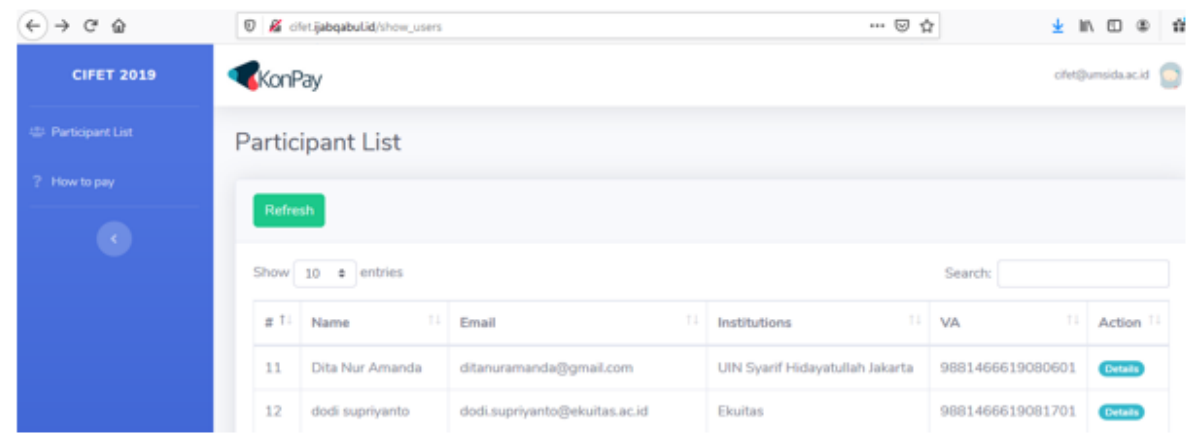

Gambar 1. Contoh pembayaran Cifet 2019

Seperti pada gambar 1, adalah metode pembayaran kepesertaan pada kegiatan Seminar Internasional "The International Seminar On Science and Religion in the Indonesia and Malaysian Education System" yang diselenggarakan tahun lalu, akad yang melatarbelakangi transaksi ini adalah akad murabahah (jual beli). Mekanismenya nasabah 
dalam hal ini mahasiswa Universitas Muhammadiyah Sidoarjo membeli tiket kepesertaan pada acara tersebut, dan oleh pihak Ijabqabul.id selaku mitra dar penyelenggara kegiatan akan diberikan virtual account yang nantinya harus dibayarkan bisa melalui teller bank penerbit virtual account bisa juga melalui ATM. Pembayaran ini bisa dilakukan secara pribadi maupun berkelompok. Mahasiswa lebih senang melakukan secara berkelompok karena memudahkan dan menghemat waktu.

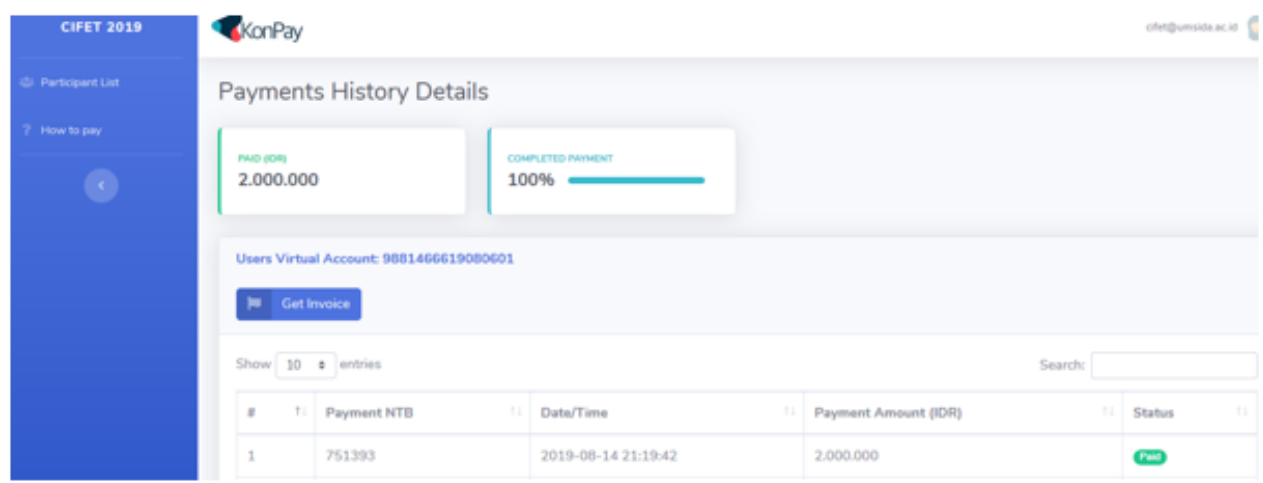

Gambar 2. Laporan pembayaran yang diterima oleh ijabqabul.id

Ketika peserta sudah membayarkan sejumlah tagihan yang didapat, seperti pada gambar 2, maka ada status pembayaran sudah dilakukan dan secara sistem akan menyimpan data tersebut nantinya akan dilaporkan secara keseluruhan.

Dalam penelitian ini tujuannya adalah untuk melihat minat mahasiswa perbankan syariah dalam bertransaksi non tunai melalui website, ini juga akan membawa dampak positif yakni mensosialisasikan kepada mahasiwa perbankan syariah tentang adanya pembayaran non tunai melalui website juga untuk mendapatkan masukan tentang kebutuhan mahasiswa dalam penggunaan transaksi itu, dalam artian bagaimana tampilan yang lebih mudah dan menyenangkan bagi mahasiswa ketika mengakses website pembayaran tersebut.

Masukan tersebut pasti akan sangat membantu dalam pengembangan website pembayaran tersebut kedepannya. Pengembangan website untuk pembayaran ini bisa berkembang dengan menambah akad-akad lain, pembayaran selain kepesertaan kegiatan, yang terutama bisa menambah jumlah yang pengguna akses pembayaran melalui website tersebut.

\section{E. Kesimpulan}

Seiring dengan perkembangan zaman dan tuntutan untuk lebih efisien dalam pembayaran maka gerakan cashless society atau pembayaran non tunai ini adalah suatu keharusan. Terutama dalam pandemi COVID 19 yang sudah mewabah secara global dan mengahruskan semua kegiatan dari dalam rumah, sehingga pembayaran non tunai merupakan hal yang sangat efektif dan sangat membantu dalam pembelanjaan semua kebutuhan dari rumah.

Dalam kegiatan mahasiswa dalam kondisi normal (tanpa pandemi Covid 19) mahasiswa seringkai mengeluhkan untuk mengikuti sebuah kegiatan seperti seminar atau 
konfrensi mereka harus antri di teller maupun antri didepan meja registrasi saat kegiatan berlangsung untuk melakukan pembayaran yang biasa disebut pembayaran on the spot, sehingga mahasiswa menginginkan kemudahan dalam pembayaran kepesertaan dalam kegiatan tersebut. Maka dengan adanya metode pembayaran non tunai melalui web ini akan sangat membantu mahasiswa dan menudahkan pembayaran. Pembayarannya bisa dilakukan secara berkelompok sehingga sangat menarik untuk mahasiswa, bisa dilihat dari perkembangannya dari $11 \%$ pada kegiatan selanjutnya meningkat lebih dari $50 \%$ pembayaran non tunai melalui website.

Dalam kegiatan penelitian ini banyak juga masukan dari responden tentang bagaimana fitur-fitur yang harus dikembangkan sesuai dengan kebuthan responden. Sehingga hasil penelitian ini nantinya akan memberikan masukan positif bagi penyedia platform yakni ijabqabul.id untuk meningkatkan pelayanan kepada penggunanya. 


\section{DAFTAR PUSTAKA}

Amalia, S. N. A. (2018). Faktor-Faktor Yang Mempengaruhi Minat Individu Terhadap Financial Technology (Fintech) Syariah (Paytren) Sebagai Salah Satu Alat Transaksi Pembayaran (PendekatanTechnology Acceptance Model (TAM) dan Theory Of Planned Behavior (TPB). Iqtishaduna, 8(1), 57-73.

databoks. (2017). Berapa Transaksi Fintech Indonesia? Transaksi Fintech Indonesia 20152021. Katadata, 2022. Retrieved from

Didin Elok Parastiti, Imam Mukhlis, A. H. (2015). Analisis Penggunaan Uang Elektronik Pada Mahasiswa Fakultas Ekonomi Universitas Negeri Malang (Studi Kasus: Uang Elektronik Brizzi). Jurnal Ekonomi Dan Studi Pembangunan, 7(1), 75-82.

Indonesia, B. (2014). Mengurangi Ketergantungan pada Uang Tunai. In Gerai Info Bank Indonesia (Vol. 50).

Keuangan, O. J. (2019). Per 30 oktober 2019. Retrieved from https://ojk.go.id/id/berita-dankegiatan/publikasi/Pages/Penyelenggara-Fintech-Terdaftar-dan-Berizin-di-OJK-per-30Oktober-2019.aspx

Kusnandar, V. B. (2019). Pengguna Internet di Indonesia 2018.

Muzdalifa, I., Rahma, I. A., \& Novalia, B. G. (2018). Peran Fintech Dalam Meningkatkan Keuangan Inklusif Pada UMKM Di Indonesia (Pendekatan Keuangan Syariah). Jurnal Masharif Al-Syariah: Jurnal Ekonomi Dan Perbankan Syariah, 3(1).

Rahmat Mulyana. (2019). The future of fintech In Light Covid 19. In Webinar Tazkia.

Siahaan, F. B. (2016). SISTEM INFORMASI PENJUALAN BERBASIS WEB MENGGUNAKAN METODE VIRTUAL ACCOUNT. SNIPTEK, 3(3), 347-352.

Taskinsoy, J. (2019). The Transition from Barter Trade to Impediments of the Dollar System: One Nation, One Currency, One Monopoly. SSRN Electronic Journal, (March).

Tazkiyyaturrohmah, R. (2018). Eksistensi Uang Elektronik Sebagai Alat Transaksi Keuangan Modern. Muslim Heritage, 3(1), 23.

Usman, R. (2017). Karakteristik Uang Elektronik Dalam Sistem Pembayaran. Yuridika, 32(1), 134.

Wardhana, B., Mukminin, M. A., Syafira, I., Isnawati, R., \& Latifah, F. N. (2020). Wo men's empowering through sharia crowdfunding. 05(01), 15-20. 
..:: Malia: Jurnal Ekonomi Islam Vol. 12 No. 1, Desember 2020 ::..

38 | Minat Mahasiswa Perbankan Syariah Melakukan Pembayaran Transaksi ... 